DOI: https://doi.org/10.34069/AI/2021.39.03.23

\title{
Apophatics of artistic culture: raising the issue. Disease, death and sleep ethoses in Alexander Grin's story "Struggle with Death"
}

\section{Апофатика художественной культуры: постановка вопроса. Этосы болезни, смерти и сна в рассказе А. Грина «Борьба со смертью»}

Received: March 4, 2021

\begin{abstract}
Object of the article: apophatics as a cultural phenomenon. Subject of the article: a method of creating an apophatic reality in a literary work, the apophatic side of the phenomenon of sleep is studied. Material of the article: an early littleknown story by Alexander Grin "Struggle with Death" (1918). Research methodology: a holistic analysis of a literary text, which is achieved through the ontohermeneutic method using the semantic research method. Research results: analysis of Grin's early story, identification of its ontological meaning, ethos of illness, death, sleep allows raising an issue of apophatics of a literary work. The appeal to anthroposophical reflections on the axiological status of sleep by the German philosopher Rudolf Steiner, whose ideas were shared by the representatives of the Silver Age, especially Maximilian Voloshin, Grin's closest friend, is also productive, since the anthroposophist highlights the apophatic side of sleep associated with day and night human consciousness. The ethos in the article is understood within the framework of Heidegger's research, which makes it possible to deepen the cultural-philosophical ideas about the phenomenon of death, disease and sleep in the
\end{abstract}

Accepted: April 28, 2021

\author{
Written by: \\ Marianna A. Dudareva ${ }^{87}$ \\ https://orcid.org/0000-0002- 4950-2322 \\ SPIN: 5362-0507 \\ Nurbek A. Omuraliev ${ }^{88}$ \\ https://orcid.org/0000-0002-4279-4852 \\ Tatiana V. Shvetsova ${ }^{89}$ \\ https://orcid.org/0000-0001-9637-6958 \\ SPIN: $8251-1780$ \\ Darya A. Aripova ${ }^{90}$ \\ https://orcid.org/0000-0002-4515-4834 \\ SPIN: 9624-3336
}

\begin{abstract}
Аннотация
Объект статьи: апофатика как феномен культуры. Предмет статьи: способ создания апофатической реальности в художественном произведении, изучается апофатическая сторона феномена сна. Материал статьи: ранний малоизвестный рассказ А. Грина «Борьба со смертью» (1918). Об этом произведении не так много работ в российском литературоведении, этот текст рассматривают только в контексте всего творчества писателя. Однако это произведение представляет особую ценность в культурфилософском осмыслении феномена сна и смерти в русском варианте логоцентризма, поскольку здесь сон выступает условием выздоровления героя, выхода из морбуального состояния. Методология работы: целостный анализ художественного текста, который достигается с помощью онтогерменевтического метода с привлечением семантического метода исследования. Результаты: анализ раннего рассказа Грина, выявление его онтологического смысла, этоса болезни, смерти, сна позволяет поставить вопрос об апофатике художественного произведения. Обращение к антропософским размышлениям об аксиологическом статусе
\end{abstract}

\footnotetext{
${ }^{87}$ Candidate of Philology, Senior Lecturer, Russian Language Department No. 2, the Russian Language and General Education Faculty, RUDN University, Russian Federation.

${ }^{88}$ Doctor of Sociological Sciences, Acting Professor of Bishkek State University named after K. Karasayev, Bishkek, Kyrgyz Republic.

${ }^{89}$ Federal University named after M.V. Lomonosov (NarFU). Arkchangelsk, Russia

${ }^{90}$ Irkutsk National Research Technical University, Irkutsk, Russian Federation.
} 


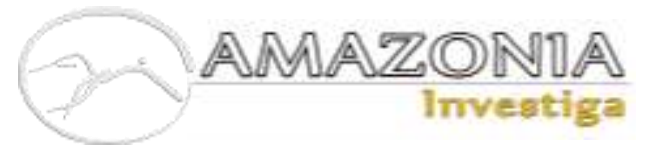

global art culture.

Key words: the phenomenon of death, the phenomenon of sleep, apophatic, ontology, A. Grin's works, anthroposophy, Russian traditional culture.

сна немецкого философа Рудольфа Штайнера, чьи идеи были близки представителям Серебряного века, особенно Максимилиану Волошину, ближайшему другу А. Грина, также является продуктивным, поскольку антропософ высвечивает апофатическую сторону сна, связанную с дневным и ночным сознанием человека. Этос в статье понимаем в рамках исследований М. Хайдеггера, что позволяет углубить культурфилософские представления о феномене смерти, болезни и сна в мировой художественной культуре.

Ключевые слова: феномен смерти, феномен сна, апофатика, онтология, творчество А. Грина, антропософия Р. Штайнера, русская традиционная культура.

\section{Introduction}

Apophatics, an ancient concept rooted in antiquity, is now spreading into all research paradigms. Apophaticism is no longer exclusively related to theology and philosophy. Certainly, it is understood that the apophatic way of knowing the Divine is associated with the denial of all predicates as false or partially false. God cannot be precisely defined in apophatic theology. However, the apophatic method can bring the researcher closer to other Absolutes of culture, which are transcendental in nature. Death is a priori incomprehensible; in Russian humanitaristics, the apophatics of death is covered in Varava's works (Varava, 2013). Disease also has the qualities of apophaticity, since the morbial state precedes death. However, sleep can also be considered in the same way, its nature is currently of interest to cultural researchers.

In the last ten years of world humanitaristics, researchers are increasingly considering sleep from a cultural-philosophical point of view, rightly pointing out the connection between sleep and human behavior: "The connection between sleep and ethical experience, more precisely, moral experience, is perhaps not so clear, since the dominant of moral experience is the sphere of behavior. Meanwhile, each person experiences moral collisions when sleeping" (Karpova, 2014, 15). However, behavior is comprehended not only when sleeping, but also after waking up, i.e. in the daytime. In this regard, the experience of global art culture, Russian literature is indicative, for which the dreaming discourse is definitely especially relevant. Attention should be paid to Pushkin's poetics, where sleep is one of the structural plot-forming units (Gershenzon wrote

about it in detail at the beginning of the 20th century (Gershenzon, 1997), then Bocharov (1974)). In addition, modern researchers rightly point to the ambivalent status of the phenomenon: "... sleep as a phenomenon is neither physiological nor completely nonphysiological in its essence, and it is about some kind of 'resonance', a mosaic combination of the objective state of the brain and the rest of the organism with the subjective state of the sleeping human spirit, and both - with the cultural institutions of the corresponding society" (Shchavelev, 2014, p. 98). However, the complexity of this cultural phenomenon lies in its nature that is apophatic for an ordinary person. Following philosophers and theologians, it talks about "daytime" and "nighttime" consciousness (Trostnikov, 2000). In this case, apophaticism is also referred to as a cultural phenomenon that has radiated into all research scientific paradigms: philosophical (Varava, 2013; Gurevich, \& Spirova, 2019), philological (Elepova, 2012; Dudareva, 2019), and culturological ones (Grachev, 2019), and is associated with many transcendental cultural phenomena (death, disease, fear). In this aspect, the observations of the early 20th-century philosopher Florensky about dreams that "have a special measure of time - a transcendental one" are of interest" (Florensky, 1993, pp. 4-5). In this way, the purpose of the article is analysis of a literary work, which is aimed at highlighting the philosophical issues of the text, identifying the ethos of life and death. 


\section{Materials and methods}

Sleep is a priori incomprehensible, but this does not mean that one should not try to approach its apophatic horizon and understand its ontological purpose. The experience of Russian verbal culture can be productive in this respect, and this article considers the apophatics of artistic culture, which is the broadest object of research, as well as the apophatic nature of sleep. The subject is the way of depicting a dream element in a literary work, an early story by Grin "Struggle with Death", which serves as illustrative material in the work. The ontohermeneutical analysis will highlight the cultural-philosophical significance of sleep. In addition, great attention is paid to the symbolic space of the story, drawing parallels with the Russian folklore tradition. Following Heidegger and Okeansky from the Russian culturological school, ethos is understood as a populated universe, a place of residence (Heidegger, 1993; Okeansky, 2011). The research methodology is reduced to a holistic otogermeneutic analysis of a literary text using the semantic method. Research results consist in a holistic cultural-philosophical understanding of the phenomenon of death, phenomenon of sleep in A. Grin's works.

The plot of an early little story by Grin centers on a character "who overcomes a serious disease, comes out of a hopeless state due to the strength of his mind..." (Shevtsova, 2003, p. 132). It is interesting how the sick Lorkh emerges from the morbial and almost thanatological state, what helps him to recover. To answer this question, the authors turn to the architectonics of the work and consistently analyze the actions of the protagonist, who is in the face of death. In this regard, the anthroposophical teaching, which was popular at the beginning of the 20th century, by Rudolf Steiner whose works contain reflections on the phenomenon of sleep and disease, will also be considered in the article.

\section{Results and discussion}

First, attention should be paid to the very beginning of the story, which is given in an apophatic way: "- I am thinking about unfinished business, - said Lorkh to the doctor. - Yes: why aren't you leaving? - Such a kind question, Dieman replied slowly, looking around intently. - The bed must be put to the window. From here, across the chasm, you can see the entire pink snow landscape. Look at the mountains, Lorkh; there is nothing better to think about" (Grin, 1965 , p. 206). When the doctor asked about the essence of this unfinished case, Lorkh tell jokes and eventually admits that he invented this case in order to find out about the day of his death: "The patient laughed barely audibly. - Suppose that Wilton will not come, - he said mockingly, - and he has no concession. But I found out what we need. The bed can really be moved to the window" (Grin, 1965, p. 207). The invented unfinished business, which does not exist at all, becomes a matter of life, changing its ontological status from minus to plus - the announcement of death marks the beginning of a new life for the patient. According to the subtle observation of the philosopher and thanatologist Varava, news of death is always frightening, since it is associated with a feeling of unbearable surprise, but it is axiologically significant (Varava, 2010, p. 9). In Grin's work, the feeling of surprise that tormented the patient is finally resolved with clarity, and mental metamorphoses begin to occur with the character.

Second, the presence of a mountain landscape with a steep cliff and a flowering white bush outside Lorkh's window is symbolic in the story: "Looking out of the window in the direction of his feet, Lorkh saw a bush of white flowers on the cliff among the stones" (Grin, 1965, p. 209). According to the laws of world mythology, the mountain personifies the World Axis (Axis Mundi), and the character completes his initiation path by reaching it. This statement can be well illustrated by examples from spell poetics: " $<\ldots>$ spells, embodying individual components of the universal semantic complex death-path, reflect the idea of visiting the spirit world in order to eliminate the initial inferiority or achieve maximum assurance of existence" (Shindin, 1993, p. 109). In this story, the window with a view to the mountains, a steep cliff and one flowering bush is a window into otherness, ceasing to be just a part of the room: "Lorkh saw a full moon in a scattering of white stars over a mountain ridge; its light fell into the chasm above the impenetrable corner of the shadow" (Grin, 1965, p. 209).

Third, all these reflections in front of the window and mountains, the unity of which organizes the sacred open space in the text, are interspersed with Lorkh's constant sleep. First, the character sleeps after a difficult conversation with his nephew, who was waiting for the death of his uncle in order to get the desired inheritance: "Lorkh fell asleep and woke up in the evening when it got dark" (Grin, 1965: 207). After that there is a scene of Lorkh lying after sleep: "Then, having decided to continue living, he carefully put his thoughts in order and realized that the most important thing is to overcome weakness. 
Lorkh stood up fast. He got dizzy. He began to swing while sitting; then, taking a knife from the night table, he stabbed himself in the thigh" (Grin, 1965, p. 209). Certainly, unlike Pushkin, Turgenev, Dostoevsky, whose heroes see colorful dreams, being on the threshold, in dying states, Grin does not have a detailed description of sleep, and one cannot even assume what the patient was dreaming about. However, the very fact of leaving the body is important, speaking in the language of anthroposophy, the main provisions of which were known to many representatives of the creative intelligentsia of the Silver Age and especially to Maximilian Voloshin (Pronina, 2005), Grin's neighbor and friend in the Cimmerian village.

Rudolf Steiner, a German philosopher, the founder of the anthroposophical doctrine, has separate lectures on the purpose and nature of sleep, which in many respects, under certain conditions, is equated to the state conventionally called "between death and rebirth". When sleeping, a person, leaving his physical body and daytime consciousness, interacts with the transcendental sphere, his "astral" body or true "I" is involved: "The physical and etheric bodies remain in bed during sleep. We distinguish from these parts the so-called body of consciousness, or - let us not be confused by this phrase - the astral body..." (Steiner, 2000, p. 148). This esoteric reasoning seems to be quite necessary, especially a similar idea of sleep as a temporary death, the ethos of sleep as a person's being in another space can be found in the world folklore tradition (for more details, see the works of an ethnographer and folklorist Tolstoy (2003)). Grin's ethos of sleep is a state "between death and rebirth".

According to Kim Ken Tae, Grin as a symbolistmetaphysician sees something more hidden from ordinary perception (Kim, n.d.) in everyday life, and does this by using the method of sleep, an altered mental state, including fantastic elements into the structure of the literary work. However, in the story "Struggle with Death", sleep is a condition for recovery, not disease or an altered mental state. After the main culminating events, his volitional actions, Lorkh falls asleep again and wakes up as a different person: "Lorkh has woken up. He looked energetic and healthy" (Grin, 1965, p. 211). Steiner also views sleep as a necessary condition for the healing of the physical and etheric bodies: "Life continues during sleep, and the forces that work and create during wakefulness draw refreshment and strength from what sleep gives them. ...A person who did not constantly take energy from sleep for his weakened forces would lead his life to destruction" (Steiner, 2004, p. 71).

Finally, fourth, oddly enough at first glance, the tree code, the torn flowers of the tree are associated with the motive of recovery. According to Slavic folklore ideas, there is a close invisible connection between man and tree: "the death of a tree entails the death of a person" (Lazareva, 2020, p. 30). In Grin's story, the patient decides to take desperate measures to either recover or die: he gets out of bed, stabbing himself with a knife, takes a fatal dose of alcohol, crawls over a steep cliff to a bush of flowers. "Then he climbed over the windowsill, walked along the wall, sobering up a little, to a bush of white flowers, tore them, came back and went to bed, undressed, under the blanket, having thrown on it all the trousers and jackets he found in the wardrobe. Having done this, he stretched out, flinched and - suddenly - lost consciousness" (Grin, 1965, pp. 210-211). On the one hand, following the folklore logic, Lorkh would have to die, as he tore the flowers from the bush, which symbolically acts as a kind of double in the story (the bush was located directly opposite the patient's bed). On the other hand, Lorkh seems to die, loses consciousness, losing the last of his strength, committing desperate deeds and risking in ontological terms. Peculiarities of "white" colorative, which are semantically associated with death, should also be taken into account. Symbolically, the character wins, overcomes death by tearing white flowers. In addition, reflections on the folklore tradition in literature always entail its transformation and hidden nature. In Grin's story, there is a kind of "dispute" with folklore, or what, according to the folklorist Smirnov, may mean dialectical "negation", definitely with elements of "removal", i.e. the productive assimilation of those potentialities that are hidden in folklore" (Smirnov, 2001, p. 4).

\section{Conclusion}

Grin's story "Struggle with Death" is interesting primarily from a cultural-philosophical point of view, revealing the apophatic side of the phenomenon of sleep, which, as a technique, became widespread in the artistic practice of the early 20th century. However, sleep in the story is perceived not as a borderline painful state, but as a necessary condition for the patient's recovery and an ontological breakthrough from darkness to light, which is characteristic of the aesthetics and poetics of the Russian fairy tale. It is more 
effective to refer to the anthroposophical teaching by Steiner, popular in the creative environment of the Silver Age, to his lectures on sleep, disease, and healing. Sleep heals not only the physical body but also gives new strength for the life of the soul, which was necessary for Lorkh, who was abandoned by his dishonest greedy relatives at the time of death. Parallels with the folklore tradition, latently expressed in the story, are also productive and necessary: sleep is equated with temporary death, which is initiatory, regenerative in nature. However, the issue of folklorism of Grin's works is a complex theoretical issue that requires separate philological developments.

Through highlighting the ontological foundations of a literary text, one can come closer to the understanding of apophaticism as a cultural phenomenon. Today, apophaticism is a condition for a genuine search for sacred cultural knowledge; though the apophatic method is provocative, it is more effective (Mikhailova, 2000 , p. 168). The spread of the pandemic has determined the thanatological nature of presentday realities, but the appeal to the literary word, to literature allows solving many issues of humanity, which is in conditions of social entropy, through the prism of art.

\section{References}

Bocharov, S.G. (1974). On the Meaning of the "Undertaker" (On the Problem of Interpreting the Literary Work). In Context. Literary Theoretical Research (pp. 196-230). Moscow: Nauka.

Dudareva, M. (2019). Apophatic elements in the poetry of S. A. Yesenin: Thanats' characters. Amazonia Investiga, 8(22), 51-57. https://amazoniainvestiga.info/index.php/amazo nia/article/view/27

Elepova, M.Yu. (2012). V.A. Zhukovsky's aesthetics in an apophatic context. Discussion, 4(22), 176-178.

Florensky, P.A. (1993). Iconostasis: Selected Works on Art. St. Petersburg: Nevsky Prospekt. (Mithril)

Gershenzon, M.O. (1997). Pushkin's Dreams. In The Wisdom of Pushkin (pp. 260-275). Tomsk: Vodoley.

Grachev, V.I. (2019). The Cultural Phenomenon of Apophatic of "Myth Dialectics" by A.F. Losev in the Context of the Topochronous-Axiogenic Cultural Paradigm. Culture of Culture, 3. Retrieved February 21, 2021, from http://cultcult.ru/cultures-the-phenomenon-of-apophaticthe-dialectics-of-myth-by-a-f-losev
Grin, A.S. (1965). Struggle with Death. In Collected Works in 6 Volumes (Vol. 4, pp. 206-211). Moscow: Pravda.

Gurevich, P., \& Spirova, E. (2019). Science in the Apophatic Horizon. Philosophical Anthropology, 5(1), 6-25.

Heidegger, M. (1993). Time and Being: Articles and Speeches. Moscow: Respublika.

Karpova, L.M. (2014). Dreams and Spiritual Experience. Humanitarian Research, 1(2), 13-16. http://www.library.fa.ru/files/Karpova1.pdf

Kim, K.T. (2000). Grin's Fantastic Novels. Alexander Green. Retrieved February 21, 2021, from

http://www.newfoundglory.ru/publikacii/fantast icheskie-novelli-grina.html\#bookmark22 121153.

Lazareva, A.A. (2020). Interpretation of Dreams in Folk Culture. Moscow: RSUH. 257 s. https://www.rsuh.ru/news/detail.php?ID=71152 3

Mikhailova, M.V. (2000). Apophatic in Postmodernism. In Symbols, Images, Stereotypes of Modern Culture (Issue 7, pp. 166-179). St. Petersburg: Eidos.

Okeansky, V.P. (2011). Life and Death Ethoses in Khomyakov's and Schopenhauer's Works (Culturological Reflections to Justify the Comparison). Solovyov Research, 3(31), 125-136.

Pronina, O. (2005). "Rouen Cathedral" by Maximilian Voloshin and "Theosophy of the Rosicrucian" by Rudolf Steiner. Antroposofía en Rusia. Retrieved February 22, 2021, from http://www.anthroposophy.ru/index.php?go=Pa ges\&in=view\&id=26\&SNS=dfb25a68a04ba8b6 e506dde9a24503f (accessed 22.02.2021).

Shchavelev, S.P. (2014). The Eternal Shadow of Reality: An Essay on the Philosophical Anthropology of Dreams. BelSu Scientific Bulletin, 9(180), Issue 28, 92-99.

Shevtsova, G.I. (2003). Artistic Embodiment of the Idea of Movement in A.S. Grin's works (Ph.D. Thesis). Universidad Estatal Yelets lleva el nombre de I A. Bunin, Yelets.

Shindin, S.G. (1993). Spatial Arrangement of the Russian Voodoo Universe: The Image of the World Center. In Research in the Field of BaltoSlavic Spiritual Culture. Spells (pp. 108-127). Moscow: Nauka.

Smirnov, V.A. (2001). Literature and Folklore Tradition: Issues of Poetics (Archetypes of the "Feminine Principle" in Russian Literature of the 19th -Early 20th Centuries): Pushkin. Lermontov. Dostoevsky. Bunin. (PhD in Philology), Ivanovo State University, Ivanovo. Steiner, R. (2000). Asceticism and Disease. In Metamorphoses of Mental Life. The Path of 
Inner Experience. Part 1. (pp. 145-174). Moscow: Evidentis

Steiner, R. (2004). Sleep and Death. In Essay on Mystery Science (pp. 70-120). Kharkiv: FOLIO. Tolstoy, N.I. (2003). Folk Interpretations of Dreams and Their Mythological Basis. In Essays on Slavic Paganism (pp. 303-310). Moscow: Indrik.

Trostnikov, V. (2000). Apophatic is the Main Method of Science of the 21st Century. Pravoslavie. Retrieved December 12, 2020, from https://pravoslavie.ru/736.html (accessed on 12.12.20).

Varava, V.V. (2010). "Deduction" of the Mind and "Induction" of the Heart (about Life and Death in Russian Philosophical Culture). Bulletin of the Voronezh State University, 2(4), 5-16.

Varava, V.V. (2013). Philosophical Thanatology or Apophatic Philosophy? Scientific Bulletin of Belgorod State University. Series: Philosophy. Sociology. Law, 2(145), Issue 23, 112-117. 